Organized Business, Political Regimes and

Property Rights across the Russian Federation

by

William Pyle

June 2007

MIDDLEBURY COLLEGE ECONOMICS DISCUSSION PAPER NO. 07-03

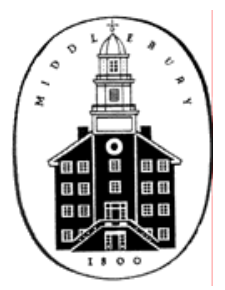

DEPARTMENT OF ECONOMICS

MIDDLEBURY COLLEGE

MIDDLEBURY, VERMONT 05753

http://www.middlebury.edu/ econ 


\section{Organized Business, Political Regimes and Property Rights across the Russian Federation}

Abstract: This article explores the inter-relationship of collective action within the business community, the nature of the political regime and the security of firms' property rights. Drawing on a pair of surveys recently administered in Russia, we present evidence that post-communist business associations have begun to coordinate business influence over state actors in a manner that is sensitive to regional politics. A firm's ability to defend itself from government predation and to shape its institutional environment as well as its propensity to invest in physical capital are strongly related to both its membership in a business association and the level of democratization in its region. Of particular note, the positive effect of association membership on securing property rights increases in less democratic regions. The evidence, that is, suggests that collective action in the business community substitutes for democratic pressure in constraining public officials.

William Pyle

Economics Department

Middlebury College

Middlebury, VT 05753

(802) 443-3240

wpyle@middlebury.edu 


\section{Organized Business, Political Regimes and}

\section{Property Rights across the Russian Federation ${ }^{1}$}

\section{Introduction}

Much of the literature on transition-era political economy portrays firms as actors whose interactions with state officials occur largely independent of one another. Whether suffering from bureaucratic predation, capturing the organs of state power, or cooperating with government officials to mitigate external pressures, post-communist firms have been viewed largely as acting alone rather than in concert with one another. Though the business community - or at least significant subsets of it - constitutes a true community in the sense of its individual members sharing interests, little attention has been given to how those interests have been shaped and pursued by organizations for collective action. This article seeks to address this imbalance. Drawing on two surveys conducted in Russia, we present evidence that post-communist business associations help secure the property rights of their members. Standing as evidence of a nascent, post-communist civil society, these organizations appear to boost some firms' capacity both to resist the state's "grabbing hand" and to guide the design of new rules and regulations.

This article also addresses the broader question of the relationship between political regimes and property rights. By exploiting the variation in electoral competition across Russia's territorial subjects, we show that in more democratic regions firms are less vulnerable to the caprice and predatory behavior of state officials. Firms in these regions, that is, appear better able to thwart corruption and to influence the evolution of formal economic institutions. Both direct and indirect causal mechanisms appear to be at work. The greater security of property observed in more democratic settings is consistent with electoral pressures serving as a direct constraint on state power. Political openness, more-

${ }^{1}$ For reading the paper and providing helpful feedback, the author would like to thank Daniel Berkowitz, Dinissa Duvanova, Gregory Kisunko, Iikka Korhonen, Peter Murrell, Jo Swinnen, and Andrei Yakovlev. The comments of departmental colleagues at our monthly brown bag seminar have also been quite useful. The author would also like to acknowledge the Irina Perova, Alexei Grazhdankin and the Levada Analytical Centre for their professional assistance in designing and administering the surveys. Much of the research for this arti- 
over, by promoting collective action, indirectly increases business' capacity to strengthen property rights.

Of particular note, we observe an interesting interaction between political regimes and organized business' role in securing property rights. Although business associations are growing fastest in the more democratic regions, the marginal effect of membership appears to be less in these regions. Although property rights are more secure, on average, for all firms in more democratic settings, they are more secure only for the subset of firms that organize in less democratic settings. This suggests that collective action in the business community acts as a substitute for broader democratic pressures in constraining state threats to property.

In general terms, the story presented here is consistent with a familiar causal framework. The distribution of political power shapes economic institutions that, in turn, structure incentives at the firmlevel to engage (or not) in productive behavior. When political forces compel public officials both to limit predatory behavior and grant non-state actors a voice in designing rules and regulations, the economic environment becomes more predictable. The relationship between effort and reward becomes clearer. And the incentives to invest become stronger.

We contribute to this narrative by considering collective action's role in a manner unique to the literature that follows in this tradition. Thematically, the article resembles the work of Mancur Olson and his co-authors. The connection they highlight between political competition and stronger property rights is echoed here as is Olson's recognition that more open politics potentially affects property rights by way of collective action. But whereas Olson regarded the organizations that democracy fosters as threats to economic development, our evidence suggests otherwise. When state actors render property rights insecure, business' motivation for organizing may be more benign than Olson suspected. Indeed, in these circumstances, the threat posed by the state may motivate collective action as much or more than narrow rent-seeking.

The article is organized as follows. Section 2 reviews literature on how the distribution of political power in a society affects the provision of property rights' protections. Section 3 discusses the history of collective action in the Russian business community and introduces the surveys used in the subsequent analysis. Section 4 then explores the firm-level and regional determinants of business associa-

cle was conducted while the author was a visiting researcher at the Bank of Finland's Institute for Economies in Transition. 
tion membership, giving particular attention to the role played by political regimes. Section 5 introduces two firm-specific "property rights" variables and highlights their relationship to association membership, regional political competition and their interaction. It also demonstrates that similar relationships hold between these variables and a measure of recent investment activity by the firms. Section 6 presents conclusions and implications.

\section{Political Power and Property Rights}

Folowing Acemoglu et al. (2004), we presume the distribution of political power in a society to be a function of both formal political institutions and the ability of social groups to solve the collective action problem and organize. Political institutions, which constitute the rules governing politics - including the "form of government, for example, democracy vs. dictatorship... and the extent of constraints on politicians and political elites (390-91)" - serve as the basis of de jure political power. Successful social coordination and the subsequent aggregation of resources can constitute an additional source of de facto political power.

Together, the two determine a society's prevailing economic institutions, including most importantly, the structure of its property rights. By way of an example germane to the themes here, Acemoglu et al. (2004) highlight Robert Bates' research on the variation in agricultural policies across the developing world. In many African and Latin American countries, Bates describes how property rights have been abused by marketing boards paying below-market prices for crops as a measure to divert resources from farmers to urban constituents. He offers the Columbian coffee sector as a noteworthy exception (1997). Even though its producers were small and not organized, they did not have to confront confiscatory policies because "the structure of political institutions, and in particular the structure of party competition, rendered them pivotal, giving them power over the political fortunes of those with ambition for office (51)..." In Kenya, successful collective action, in the form of the Kenya National Farmer's Union's lobbying efforts, produced policies that were similarly respectful of property rights (1981).

\subsection{Political Regimes}

Although arguments that politics affect property rights are not uncommon, there is neither a consensus as to how they do so, nor is there a great deal of contemporary evidence that demonstrates a link. Drawing on historical evidence, North (1990) connects the spread of democratic freedoms to the evolution of more secure property rights. Democracy, he argues, not only enhances the voice of 
those bearing the burden of socially detrimental policies, such as the under-provision of property rights' protections, it "eliminates the capricious capacity of a ruler to confiscate wealth (51)." Citing growth patterns of European cities between 1050 and 1800, De Long and Shleifer (1993) make a similar point. "Absolutist" princes, they argue, presided over slower growth because they taxed to maximize own revenue; less autocratic governments, more responsive to social pressures, had to be more concerned with private economic prosperity and thus tended to be more respectful of property rights.

Olson (1993), perhaps, lays out the political incentives of democratic majorities and autocrats most clearly:

Though both the majority and the autocrat have an encompassing interest in the society because they control tax collections, the majority in addition earns a significant share of the market income of the society, and this gives it a more encompassing interest in the productivity of the society ... Democratic political competition, even when it works very badly, does not give the leader of the government the incentive that an autocrat has to extract the maximum attainable social surplus ... (570-71)

Political leaders in more democratic settings, in other words, have a stronger self-interest in promoting "good" economic institutions. Olson and co-authors show with recent data that measures of autocracy at the country level are negatively and strongly correlated with several proxies for property rights' protections (Clague et al., 1996). They conclude that democratic freedoms and property rights spring from the same institutions and are complementary: a "democracy without any property rights $\ldots$ is not in the feasible set (245)."

Not all agree, however, that the major threat to property rights resides in an unconstrained sovereign. As Przeworski and Limongi (1991) note, nineteenth century conservatives and socialists alike believed that widespread suffrage and freedom of association would empower the dispossessed, threatening the propertied classes. Moreover, they point out that if democracy promotes greater property rights' security, a clear correlation between regime types and economic growth across countries should be observed. Evidence on this score, however, has been at best mixed.

\subsection{Social Coordination}

Ironically, Olson $(1982,1997,2000)$ also plays up the possibility that non-state actors may threaten property rights in democratic settings. The same forces which facilitate capital accumulation by constraining political power also, over the longer term, enable collective action for the purposes of redis- 
tribution. A small group of firms, for instance, may organize so as to capture the political process and orchestrate a diversion of resources in its favor. Olson, however, may be a bit too quick both to assume the worst about collective action in democratic settings and to suggest that the less benign version of collective action is any more likely in democratic settings than under other regime types. Although firms in more democratic settings, almost by definition, confront lower costs of organizing, it is unclear whether the benefits of associational activities rise or fall as political competitive changes. Compared to public officials in more competitive settings, those operating where democratic pressures are particularly weak may be more sensitive to the voices of special interests intent on pushing policies that subvert the general interest. Finer (1997) and Damaska (1986), for instance, in noting how small, well-organized elites can endanger development objectives, argue that the power of these groups is more likely to be problematic in politically less competitive settings. Narrowly-focused interest groups, that is, are apt to wield more influence when constraints on executive authority are minimal.

Not all scholars share these suspicions of social coordination. Putnam (1993), notably, views civil society groups as broadly supportive of democratic and development objectives. The association of individual actors with divergent interests tends to moderate social divisions and contribute to collaborative advocacy for broad social interests. Weingast (1997) makes the connection between social coordination and property rights' protection more explicit. He argues that property rights become secure for a broad cross-section of economic actors when social groups have mechanisms by which to coordinate their response to any infringement of property rights by a sovereign. Only in the presence of such mechanisms is it in the sovereign's self interest to respect limits on his behavior.

Similar themes have been picked up on in studies devoted specifically to business community coordination. Some have argued that businesses acting in concert with one another are more apt to push for the provision of public goods than businesses acting alone (Lambsdorff, 2002). Direct, individualized lobbying tends to result in private benefits for the lobbying party as well, potentially, as government officials at the expense of other firms. The efforts of business organizations, however, may be less distortionary in that they are more apt to reflect a broader array of interests. Indeed, recent research suggests that corruption and formalized lobbying are substitutes, with the supplanting of the former by the latter being correlated with higher levels of economic development (Campos and Giovannoni, 2007; Harstad and Svensson, 2006). Doner and Schneider (2000), moreover, present evidence that 
business associations play an important roll in mitigating the types of state failures that can be particularly acute in developing countries. By both diminishing free rider problems and aggregating political power, business associations are more apt than individual firms to push for and realize welfareenhancing improvements in public administration and stronger guarantees of property rights. Schneider (2004), however, is agnostic as to whether these public-good-like benefits from business coordination are more or less apparent in democratic settings.

\subsection{Business' Power during the Transition}

Scholarship on the post-communist transition has given nascent business organizations short shrift when considering how firms pursue interests vis a vis the state. In most treatments, this disregard is implicit. Firms, that is, are portrayed almost exclusively as engaging in personalized exchanges with government officials. For instance, Hellman et al. (2003) focus on the firm-specific correlates of "influencing" or "capturing" state officials. "Captor firms," which make payments to public officials to secure favorable policies), report improvements in the security of their property rights, particularly in environments in which other firms also strike similar deals. The authors disregard the roll of associational membership on firm strategies and performance even though they had collected such data. Other analyses have more explicitly considered the role of business associations but concluded that collective action problems have minimized their significance (Gelbach, 2006).

There are several noteworthy exceptions to this general trend. On the basis of Russian survey data, Frye $(2002,2004)$ shows that of those firms reporting at least some success in influencing new laws and regulations at the federal level, half reported having used the services of business organizations. He also demonstrates a strong correlation between association membership and a firm's propensity to invest. Campos and Giovannoni (2007) draw on the same cross-country dataset as Hellman et al. (2003) and Gelbach (2006) to show that lobby membership is positively related to firms' self-reported influence on officials in the legislative and executive branches. And Duvanova (forthcoming), utilizing the same data, demonstrates a strong correlation between firms' perception of bureaucratic corruption and business association membership. In the same article, she presents convincing case study evidence from Russia of a causal link between corruption and subsequent business association development.

\subsection{Summary}


The literature review to this point serves as an introduction to the questions that are central to this paper. In broad terms, the interest here lies in the relationship between the distribution of political power and the security of property rights. As noted, political power is taken to be a function of both formal political institutions - i.e., regime type - and successful collective action within the business community. For one, we explore the independent effects of both regime type and collective action on property rights. Do firms appear to be more secure in their property rights, ceteris paribus, in (a) more democratic settings and (b) as members of collective action associations? The existing literature speaks to these questions but not with a single voice. We are also interested in the largely unexplored question of the inter-relationship between collective action and political institutions. To this end, we explore the relationship between regime type and association growth as well as the marginal (property rights) effect of membership in more and less democratic settings.

\section{Russian Business Associations and Survey Data}

\subsection{History of Russian Associations during the Transition Period}

Many of the first Russian associations grew up to promote interests of small private initiatives that were permitted during the late Soviet period. ${ }^{2}$ Others that date back to this era were organized by large state enterprises that shared an interest in preserving inter-firm ties and access to state subsidies as the mechanisms of centralized economic coordination evaporated. Some associations were established from the top down by ministry officials as their own hedge against the uncertainty of the future (Lehmbruch, 1999). And still others probably served as fronts for corrupt or profit-motivated ventures. Generally speaking, these first associations were neither well organized nor transparent in purpose (Sulakshin and Romanikhin, 2003). Two noteworthy exceptions include the two associations that to this day remain the most developed and influential, the Russian Union of Industrialists and Entrepreneurs (RSPP) and the Chambers of Commerce and Industry (TPP).

RSPP first developed as a powerful alliance of Soviet-era enterprise directors that in the initial stages of the reform era lobbied for the retention of many price controls, continued access to state subsidies and strict limits on foreign investment (McFaul, 1993; Hanson and Teague, 2005). By the mid- to late-1990s, it had developed a network of affiliated associations to provide information as well as consulting, legal and accounting services to members throughout the country. And at the federal

\footnotetext{
${ }^{2}$ Much of this section draws on the narrative in Pyle (2006a).
} 
level, its "expert" institute actively participated in the drafting of the state's economic programs and was consulted on bills before the Duma. After the 1998 financial crisis, its federal-level organization adopted a more pro-market orientation. Almost no attention has been given to the activities of its legally independent affiliates in territorial subjects throughout the Russian Federation.

Like the affiliates of RSPP, the Chambers of Commerce and Industry (TPP), which are operated independently in each of Russia's 87 territorial subjects, draws their membership from many different sectors of the economy. Regulated through a special 1993 law that guarantees their independence from state bodies, the TPP network traces its roots to a communist-era institution that promoted commercial ties with the non-communist bloc. Compared to the RSPP, it has generally maintained a lower political profile and has focused more on service provision to members. As with the RSPP, relatively little has been written of its activities, particularly those of the 170-plus independent Chambers that operate at the regional and municipal levels.

The reforms of the 1990s also gave rise to a wave of national-level, sector-specific organizations as well as a number of multi-sector and sector-specific organizations that operate at the regional and municipal levels. Although the lack of a comprehensive registry has rendered an accurate accounting of their numbers impossible, one recent estimate puts the numbers of business associations nationally at close to five thousand. ${ }^{3}$

\subsection{Surveys of Russian Associations and Firms}

In light of the lack of comprehensive sources of information about their political (and economic) activities and influence, three separate surveys were administered by the author in 2003 and 2004. First, to assess membership rates by firm size and sector, a simple screening survey of over 1300 enterprises was carried out in 48 territorial subjects of the Russian Federation. ${ }^{4}$ The findings were then used to construct a sample for a more detailed survey of 606 firms. An effort was made to achieve roughly equal distribution across both industries and the regions sampled. By construction, roughly half of the firms were to be members of associations [see map of regional distribution]. The screen-

\footnotetext{
${ }^{3}$ July 2005 interview in Moscow with Director of the Department for Cooperation with Business Associations at the Chamber of Commerce of the Russian Federation.

${ }^{4}$ For more information on the construction of the samples as well as summary data from the screening survey, see Pyle (2006a).
} 
ing survey's findings of membership rate variation across branches and employment size were used to weight the sample's distribution of members and non-members across these two dimensions.

In addition to standard firm-specific information, the survey asked firm managers a series of questions about their interaction with business associations. Some of these association-specific questions were directed at all firms and some were only designed to be answered by members of associations. This latter group included a series of questions about the two associations most important to the enterprise. Of the 280 (or 46.2\%) firms in the survey that belonged to at least one association, 88 belonged to at least two. Using the information provided on these 366 memberships, we calculated the share of firms in the sample that belong to associations of different types. As can be seen in Table 1, $39.4 \%$ of firms in the full sample belong to at least one regional association (i.e., one whose membership is derived almost exclusively from a single territorial subject), whereas only $9.6 \%$ belong to a federal or multi-regional association. Of firms that belong to regional associations, the overwhelming majority belong to multi-sector associations. Finally, we see that roughly equal numbers joined the regional associations before and after 1998, the final full year of the Yeltsin administration and the last year of the country's prolonged period of economic decline.

A third survey was administered to the directors of two hundred independent business associations. In the absence of an official registry, a variety of sources were used to construct a sample of active associations that we feel is broadly representative in terms of regional distribution, the mix between sector-specific and multi-sector associations and the importance of RSPP affiliates and the TPP network. Among this group, 145 associations were "regional" in the sense of drawing their membership almost exclusively from a single region.

Because we exploit regional variation to understand the inter-relationship among political regimes, property rights and collective action, we are interested less in the role of federal-level business associations than those that operate on a regional level. In Table 2, we present summary data on the members and non-members of these regional associations. With the exception of average firm size, the differences between the two populations of firms are not terribly striking. Clearly, however, members of regional associations tend to be larger than non-members, a finding that is mirrored elsewhere 
in the world and is consistent with larger firms having a greater capacity both to absorb membership dues and to influence the activities of the associations they join. ${ }^{5}$

A rough sense of how flows into regional associations have changed across time can be gleaned from the years in which our surveyed firms report having joined. As we can see in Table 3, a small minority reports having entered their regional associations in the Soviet era. After 1992, entry has been steady but seems to have picked up after the period of economic decline that ended in 1998. Indeed, the biggest spike in membership occurs during Putin's first years in office, a period that corresponds with a rapid acceleration in economic growth. Table 3 also provides information on the founding dates of the associations in our sample that operate at the regional level. Roughly half were established in 1995 or before; roughly half were established afterwards.

\subsection{Association Services}

Business associations the world over engage in a wide range of activities. Like many of the organizations that populate civil society, their functions can be divided along two dimensions. First, they help develop and strengthen "horizontal" ties among non-state actors. Perhaps most notably, they contribute to the provision of a public good by facilitating inter-firm information flows on the reliability of potential customers and suppliers (Pyle, 2005), as well as on new technologies and market opportunities. They also may assist, either directly or indirectly, in the resolution of inter-firm disputes (Pyle, 2006b). Business associations can also be instrumental in the "vertical" relationship between the business community and state actors. They may aggregate and transmit business interests to state bodies as well as protect the communities that they represent from abuses of state power. Indeed, our survey data show that many regional associations report offering, and many members report receiving, both types of services.

In Table 4, we report on three of the distinct vertical services addressed in the surveys: lobbying government officials, participating in the legislative process and protection from illegitimate government interference. The managers of both firms and the associations were asked to consider the importance of each of these services. The members of regional associations were asked to evaluate how critical

${ }^{5}$ Of those that were not members of associations, roughly $10 \%$ cited the membership fees and $20 \%$ cited the time demands as a reason for not joining. Golikova (2007) also finds from even more recent survey evidence in Russia that larger firms are more apt to be members of an association. 
the services were to the development and well-being of their enterprise on a scale from 0 to $5 .{ }^{6}$ Table 4 reports the percentage of those member firms that assessed the service's importance as a 4 or 5 . Smaller members, perhaps unsurprisingly, place more value on the protection received from illegitimate government interference.

We also categorize member firms by the year in which they joined a regional association. Using 1998 as the dividing point, we observe that the most noteworthy difference between firms that joined earlier and those that joined later is in the value given to participating in the legislative process. Specifically, those that report joining more recently receive greater value from the association's ability to providing them access to the legislative process.

In the last two columns, we provide the assessments of business association managers as to these same services. They were asked, as well, to assess on a scale from 0 to 5 the "importance" of the service to their association both at the time of their founding and when the survey was administered. As with the firms' managers, we record the percentage of respondents who answered with a 4 or 5 . We first note that relative to the managers of member firms, the managers of the associations attach greater importance to the vertical functions. But this difference need not be a surprise. It is possible, of course, that association managers possess an exaggerated sense of their organization's importance. But it may also be the case that they have a fuller understanding of their services' value, particularly if they are provided directly by association personnel directly. Another noteworthy feature of Table 4's data is the reported increase in "participation in the legislative process." In the year in which the associations were founded, this function was easily the least important on this list. But by 2004, it ranked just behind lobbying as the most important. This jump and the comparative data on firms joining before and after 1998 point to a growing formalization of business associations' role in the legislative process. ${ }^{7}$

\section{Determinants of Membership}

Unlike in some continental European countries, business association membership in Russia is voluntary. Provided that firms pay required dues, the survey evidence suggests that there are few, if any,

6 A " 0 " denotes the association to which the firm belongs does not offer the service; a " 1 " denotes that the association offers the service but it makes "no impact" on the firm's well-being; a " 5 " denotes that the service has an "extremely large" impact on the firm's well-being.

${ }^{7}$ Golikova (2007) highlights a similar trend using data from a retrospective panel. 
barriers to joining and retaining membership. ${ }^{8}$ For instance, we found little evidence that associations are exclusive clubs. Only one (of 326) non-members in our survey reported having been denied admission to a business association. And of current members, only one-sixth reported knowing of an instance in which their association had expelled a member. Most of these cases related to financial issues (e.g., not paying dues), while a smaller number stemmed from a member's violations of established behavioral norms.

If membership is largely a matter of choice, it is worth considering the factors that influence a firm's decision. We thus set up a probit model in which the dependent variable is membership in a regional association. To evaluate whether or not the determinants of membership have changed over time, we use the cutoff point of 1998, running the model once with the dependent variable capturing whether the firm joined a regional association in 1998 or before and once with it reflecting whether the firm joined an association after 1998.

Applying an expected cost-benefit calculus, we hypothesize that the decision to join an association is a function of both firm-specific and regional characteristics. With respect to the former, we anticipate that a firm's size (as measured by its employment level in 2001) will affect its capacity to pay membership dues as well as to influence the agenda of an association once it joins. Thus, ceteris paribus, larger firms should demonstrate a greater proclivity for joining.

We also consider factors that may reflect a firm's access to alternate mechanisms for influencing state actors. For instance, older firms as well as those that are state-owned, may have access through other, perhaps less formal, channels that do not require the mediation of a formal organization. We thus include dummy variables for both state ownership and establishment in the post-Soviet era. If our hypothesis about alternate channels of influence is correct, we would expect that state-owned firms would be less likely to have joined associations, while those firms without roots in the old system would be more likely to have become members.

We also include a dummy variable whose value is a function of the firm's geographic location. If the firm is located in a territorial subject's capital - nearly always the biggest city in a given region - its proximity to other firms makes it more likely to discover the benefits of associational membership

8 There is a great deal of variation in reported annual dues for regional business associations, but the average is roughly five hundred dollars. There is strong positive correlation between reported dues and the size of the enterprise. 
and, possibly, participate in the "horizontal", network-building activities sponsored by the association. And finally, we include sector-level controls.

At the regional level, we consider one economic and one political variable. We include the region's per capita income level in 2001 because in cross-country studies, measures of economic development have been shown to be positively correlated with lobby membership (Bischoff, 2003; Campos and Giovannoni, 2007). We also include a measure of regional democratization. We suspect that in more democratic settings the costs of business coordination will be lower. State officials in less democratic regions, that is, likely make it harder for civil society organizations to operate even if their stated purpose is apolitical. Less democratic governments tend to be more suspicious of independent organizations since they may serve as a basis for future political opposition (Przeworski, 1991). But since the relative benefits from group membership in democratic and non-democratic setting are ambiguous, we have no strong ex ante expectation as to the relationship between regional democracy and membership.

The "democracy index" is a joint product of the Public Expertise Institute, the INDEM Foundation and the Merkator Analytical Center, three independent and respected Russian organizations. Their rating of individual regions takes on values between 1.0 and 5.0 (in increments of 0.5 ) and is based on the premises that more democratic regions should (a) adhere more closely to the "one person, one vote" principle, (b) demonstrate greater turnover in the executive branch, and (c) exhibit a higher level of political competition and diversity of representation in the legislature. Specifically, their index aggregates ten years of electoral data based on several objective indicators: time in office of the sitting governor; the number of competitors in regional gubernatorial elections and the difference between the winner and the nearest competitor; the share of "Edinaya Rossiya" (the "party of power") in the regional parliament; the threshold (i.e., minimum percentage of votes) for a party to qualify for seats in the regional legislature; the participation rate in parliamentary elections (wherein proximity to $100 \%$ is taken to indicate coercion or fraud); and a measure of the difference between the percentage of votes received by party candidates and the percentage of seats held by those parties in the legislature. The results of their research have been publicized in Novaya Gazeta, perhaps the most highly re- 
spected independent newspaper in contemporary Russia. Table 5 presents both the two regional variables for those regions in which the survey of firms was conducted. ${ }^{9}$

The results from the probit regressions are presented in Table 6. As suspected, larger firms have been more likely to join regional business associations. This finding is robust to the time frame; larger firms were more apt to join after 1998 as well as in or before that year. Additionally, our proxies for a firm having alternate channels through which to influence state actors demonstrate some relationship to regional association membership. Firms established in the Soviet era have been less likely to join business associations. Firms that were state-owned at the time of the survey, moreover, were less likely to be members of associations; although this relationship was statistically significant only for those firms that joined an association in 1998 or before.

The coefficients on the regional capital variable are suggestive of a dynamic in which associations' growth was initially largely confined to the capital city but has since expanded to other parts of the territorial subject. We also observe that regions that were wealthier in 2001 had somewhat more membership growth in or before 1998, whereas less wealthy regions seem to have had more growth in the years since.

Finally, we observe a very strong and positive correlation between the democracy index and membership in regional associations. But the precise source of this relationship is not clear. There are good reasons to suspect why democratic governance may increase a firm's ability to join a business association. But it could also be plausibly argued that causation runs in the opposite direction. Perhaps in those regions experiencing the most robust growth of associational membership, the growing associations have pushed regional politics in a more democratic direction. The models that explore the time effects of membership provide some guidance on this question of causation. If democracy - as measured by a partly retrospective index that aggregates ten years of electoral data since the mid1990s - drives associational membership, we should expect to see a stronger relationship between it and post-1998 membership than between it and pre-1998 membership. But if associational member-

\footnotetext{
${ }^{9}$ As a test of the democracy index's validity, we used a survey question that asked firm managers "Which parties, if any, does your firm seek assistance from to influence the content of new laws and regulations that will have an impact on your business?" The responses included legislators, the media, trade unions, executive branch personnel and influential individuals (e.g., business people). The first three institutions tend to be broadly representative of social forces and democratic freedoms. Indeed, firms in regions with a higher score on the index were more likely to report seeking assistance from these three, effects that were all significant at
} 
ship drives democracy, we might expect to see the opposite in the sense that those regions in which early membership was more likely had subsequently become more democratic. The data, however, conform more closely to the former story. Regions scoring higher on the democracy index have witnessed the fastest growth in recent years in their regional business associations. More democratic regional regimes, in other words, seem to be more encouraging of business collective action.

\section{Business Coordination and Property Rights}

Having discussed the determinants of association membership, we turn to membership's relationship to the security of property rights. Prior research suggests that mechanisms that facilitate social coordination can be critical to the state's respecting for property rights on more than just a selective basis (Weingast, 1997). Successful coordination mechanisms have the capacity to sustain an equilibrium in

which any actor that is party to the coordination commits to punishing encroachments against any other participant in the coordination mechanism. Facing the prospect of a collective response, state actors choose to observe the property rights of all coordinating parties. Some, indeed, have suggested that business associations play this role in emerging market contexts (Doner and Schneider, 2000; Duvanova, forthcoming).

\subsection{Protection from Bureaucratic Predation}

We first consider the capacity of firms to defend themselves against government predation. All firms in our survey were asked whether in the previous three years, they had experienced any "unplanned inspections" - i.e., an un-scheduled visit from an employee of a government agency. In the Russian context, the phrase has effectively become a euphemism for bribe extraction. Indeed, in an attempt to combat this sort of petty corruption, a special law was passed in the summer of 2001 formally restricting the number of visits that representatives of state agencies (e.g., tax, fire safety, police, sanitary inspection, etc.). Nevertheless, firms have continued to complain about multiple unplanned inspections (CEFIR, 2005). Often, firms simply provide the government official with a "voluntarily offered payment" in exchange for forgiving a purported violation. Some firms, however, choose to appeal to a third party (Azfar and Thomas, 2005).

Since appealing an unplanned inspection is a choice, we would expect it to reflect considerations of the relevant costs and benefits. Choosing not to appeal could be interpreted as an implicit acknowl-

the $5 \%$ level. Firms in more democratic regions were no more likely to rely upon personnel in the executive 
edgment by the firm that it does not have the wherewithal to overturn the results. If the probability of over-turning the results is sufficiently low, it selects not to incur the costs of an appeal. A firm that appeals, however, signals by its choice a belief that it possesses the ability to change the inspection's result. Our particular interest here is whether or not this willingness to stand up for one's property rights vis a vis state officials is sensitive to membership in a regional association and/or the measure of region-level democratization.

Of the firms that responded to the question about having experienced an "unplanned inspection" in the previous three years, 67.9\% (410 of 604) reported that they had. A large subset of these, 342 firms, reported disagreeing either with the necessity for the unplanned check(s) or with the result(s). Of these firms, 59.1\% did not appeal to any third party, choosing presumably to comply with a "ruling" with which they did not agree. The remaining firms sought out the assistance of at least one third party. Roughly one-fifth of the firms that reported disagreeing with the necessity or the results of the un-planned inspection appealed either to a commercial (arbitrazh) court or to other government bodies (21.3\% and 20.5\%, respectively). In other words, they appealed to government institutions for redress against the behavior of a "rogue" bureaucrat.

To assess the determinants of firms' responses to inspections with which they did not agree, we undertake a series of probit-type regressions. Since firms may derive power over state officials from their control over labor by implicitly trading votes or other assets for influence, we control for the number of full-time employees (Shleifer and Vishny, 1994). We also control for a firm's access to informal channels of influence. State-owned enterprises as well as those with roots in the pre-Soviet era may have special ties with powerful state actors that may increase the potential payoff from an appeal (Hellman et al., 2003). Controls are also included for the influence of foreign owners and the firm's membership in a commercial group. Finally, since it is quite conceivable that the cost-benefit calculation surrounding the decision to appeal is influenced by regional factors, including the political environment, we control for regional democratization and per capita income.

As shown in Table 7, we find that smaller firms were less likely to pursue the proactive strategy. Larger firms are both more likely to appeal to the court as well as to government officials. The models also demonstrate a fairly strong relationship between the decision to appeal and regional characteristics. Firms in wealthier regions, all else equal, are more apt to behave proactively. Specifically, they 
more frequently appeal to non-court government bodies. Democracy also appears to be associated with a more vigorous defense of property. But this effect is tempered when a control is included for the firm's membership in a regional business association.

Most notably, the results in Table 7 indicate that even when controlling for regional democratization, business association membership is positively and strongly associated with appealing to both the arbitration court and to other government bodies. Members" proclivity to not passively accept the "results" of an unplanned inspection is consistent with the theoretical argument and prior case study evidence that membership in an organization for collective action increases a firm's capability to punish state officials for violating its property rights (Weingast, 1997; Doner and Schneider, 2000). Perhaps exploiting this potential, association members may face lower costs of accessing officials that are able to rectify an unjustly imposed penalty. ${ }^{10}$ The relationship may additionally be a function of associations' collection and dissemination of information on how to best handle problems with corrupt government inspectors. Of regional association members, 9.4\% report having used the associations for some form of legal information/consulting services.

\section{$\underline{5.2 \text { Exercising Voice in the Design of New Institutions }}$}

From the break-up of the Soviet Union until the present day, Russia's territorial subjects have exercised a good deal of autonomy in the drafting of laws and regulations governing economic activity (Stoner-Weiss, 2006; Solanko, 2003). Table 4, recall, presented response data from the managers of both firms and business associations suggesting that associations have played a meaningful role in this process. But this evidence did not directly address the relative influence of members and nonmembers. Observing that member firms have a greater voice than non-members in designing economic institutions would provide further support for the proposition that the associations do, indeed, help to shape public policy and constrain state officials.

The surveyed firms were all asked whether or not in the previous three years representatives from their firms had been asked to participate in any "working groups" that were assisting in the drafting of regional laws and regulations deemed important for their business. If they responded positively,

\footnotetext{
${ }^{10}$ Most associations report having drawn the majority of their personnel from industry, often from the associations' members. Roughly one-third have recruited from executive branch agencies. Within the group of directors that work full time for an association, a quarter had been employed previously at an executive branch agency. And one-eighth of the directors report being members of either the State Duma or regional legislatures.
} 
they were then asked to assess the degree to which they had influenced their final contents. Of all the surveyed firms, $23.9 \%$ reported having been asked to participate in such regional "working groups" during the previous three years.

As can be seen from the results of the probit model reported in the first column of Table 8, although regional democratization and economic development are positively related to a firm having been asked to participate, neither of theses variables is related in a statistically significant manner to having been invited to participate in these sorts of forums. Instead, firm-specific characteristics seem to be more important determinants. Younger and state-owned firms, all else equal, are less likely to have been invited. Of greatest interest to us, however, is the positive and strong association between regional association membership and having been asked to participate formally in the drafting of laws and regulations at the regional level. This finding, in conjunction with the data in Table 4, suggests that regional legislative bodies are increasingly viewing business associations as intermediaries in the state-business dialogue. And in fact, anecdotal evidence suggests that associations are often now contacted by legislative representatives for suggestions of firms that should assist in the drafting of new laws and regulations. ${ }^{11}$

Table 8 also includes the results from an ordered probit model in which the dependent variable is a firm's assessment of the extent to which it had influenced the final product of the drafting process. Firms that reported having participated in such working groups during the previous three years were asked about the frequency of their influence on this process. Among the 145 respondents, 54.5\% answered "never," 26.2\% “occasionally," 13.8\% "often" and 5.5\% responded "always." Not surprisingly, larger firms report greater influence in these forums (Shleifer and Vishny, 1994)

More notably, Table 8 demonstrates that membership in a regional association is strongly and positively associated with having an impact on the design of new economic institutions. Business association members are more likely to be included in working groups and, once having been selected, are more likely than other participants to influence the drafting process. Column 3 reveals, however, that this effect is sensitive to the measure of regional democratization. The inclusion of a variable interacting regional association membership and the democracy index reveals that members' influence relative to non-members is greater in less democratic regions. Furthermore, it demonstrates that nonmembers in more democratic regions have greater influence than non-members in less democratic

${ }^{11}$ Author interview with employee of Coordinating Council of Employers' Associations of Russia. 
regions, ceteris paribus. The interaction effect is significant at the $5 \%$ level, whereas both the independent democracy and business association effects are significant the $1 \%$ level.

These results are consistent with the proposition that in the context of influencing the design of economic institutions collective action may substitute for democratic pressures. At least in this one sense, membership in a business association appears to become more desirable for a firm when the likelihood of state actors responding to broad social pressures diminishes.

\subsection{Property Rights and Investment Incentives}

If the proxies for the security of firms' property rights are appropriate, we would expect the same variables that are closely correlated with them would also be strongly associated with a greater propensity to invest. Testing this, we use a survey question that asks whether or not a firm had invested in its capital stock in the previous three years. Table 9 presents the results from a probit regression in which the response to this question is the dependent variable. Indeeed, when controlling for the interaction between regional democracy and association membership, we once again observe that the independent effect of association membership is positive and significant. The same is true of the independent democracy effect. Moreover, the interaction of the two is statistically significant and negative in the manner observed in the model that assessed the determinants of exercising influence over regional laws and regulations. As above, these findings suggest a larger marginal effect of association membership in less democratic regions, further lending support to the notion that collective action serves as a substitute for democratic pressures in terms of protecting firms' property rights. All firms in democratic regions, that is, feel relatively secure in their property rights. But, ceteris paribus, the subset of firms that participate in collective action feel more secure in regions in which public officials are relatively less constrained by democratic pressures.

\section{Conclusion}

This article arrives at several conclusions about the property rights' effects of political regimes and collective action in the business community. Firms in more democratic regions appear better equipped to protect themselves from bureaucratic predation and to influence the design of new rules and regulations that are relevant to their line of business. These findings are consistent with political competition limiting government caprice and predation and would appear to support the arguments of democratic optimists like North and Olson. As Olson suspected, democracy appears to encourage collective action, but this indirect effect of more open and competitive political regimes is more be- 
nign than he feared. Indeed, in an environment like Russia's in which state actors represent a threat to property rights, self-defense (rather than redistribution) may develop into the principle motivator of business coordination through formalized structures. For as we observe, controlling for regional politics, there is a strong correlation between association membership and the security of a firm's property rights, a finding that only confirms the testimony of some firms and most association directors that a primary function of business associations is to preserve firms' property rights. Finally, the evidence that business associations serve as a kind of substitute for democratic pressures is of particular note. At the least, this result suggests that the interaction between political institutions and collective action deserves more attention. 


\section{Sources Cited}

Acemoglu, Daron, Simon Johnson and James Robinson, 2005). "Institutions as a Fundamental Cause of Long-Run Growth," in eds., Philippe Aghion and Steven Durlauf, Handbook of Economic Growth, Volume 1, 385-472. North Holland Press.

Azfar, Omar and M.A. Thomas, 2005. Russia: Corruption and Transparency in Business Registration and Regulation. USAID.

Bates, Robert, 1981. Markets and States in Tropical Africa: The Political Basis of Agricultural Policies. Berkeley: University of California Press.

Bates, Robert, 1997. Open Economy Politics: The Political Economy of the World Coffee Trade. Princeton: Princeton University Press.

Bischoff, Ivo, 2003. "Determinants of the Increase in the Number of Interest Groups in Western Democracies: Theoretical Considerations and Evidence from 21 OECD Countries," Public Choice, 114, 197-218.

Campos, Nauro and Francesco Giovannoni, 2007. "Lobbying, Corruption and Political Influence," Public Choice, 131, 1-21.

CEFIR, Monitoring the Administrative Barriers to Small Business Development in Russia: The Fifth Round, 2005, accessed July 21, 2006, http:/ / www.cefir.ru/index.php?l=eng\&id=32.

Clague, Christopher, Philip Keefer, Stephen Knack and Mancur Olson, 1996. "Property and Contract Rights in Autocracies and Democracies, Journal of Economic Growth, 1, 243-276.

Damaska, Mirjan, 1986. The Faces of Justice and State Authority: A Comparative Approach to the Legal Process. New Haven: Yale University Press.

De Long, J. Bradford and Andrei Shleifer, 1993. "Princes and Merchants: European City Growth before the Industrial Revolution," Journal of Law and Economics, 36, 671-702.

Doner, Richard and Ben Ross Schneider, 2000. "Business Associations and Economic Development: Why Some Associations Contribute More Than Others," Business and Politics, 2, 261-288.

Duvanova, Dinissa, forthcoming. "Bureaucratic Corruption and Collective Action: Business Associations in the Post-Communist Transition," Journal of Comparative Politics.

Finer, Samuel, 1997. The History of Government. Cambridge: Cambridge University Press.

Frye, Timothy, 2002. "Capture or Exchange? Business Lobbying in Russia," Europe-Asia Studies, 54, 1017-1036.

Frye, Timothy, 2004. "Credible Commitment and Property Rights: Evidence from Russia," American Political Science Review, 98, 453-466.

Gehlbach, Scott, 2006. "The Consequences of Collective Action: An Incomplete-Contracts Approach," American Journal of Political Science, 50, 802-823.

Golikova, Victoria, 2007. "Membership of Russian Companies in Enterprise Associations," in eds. Svetlana Avdasheva, Victoria Golikova, Fumikazu Sugiura and Andrei Yakovlev, External Relationship of Russian Corporations. The Institute of Economic Research, Hitosubashi University. 
Hanson, Philip and Elizabeth Teague, 2005. "Big Business and the State in Russia," Europe-Asia Studies, 57, 657-680.

Harstad, Bard and Jakob Svensson, 2006. "From Corruption to Lobbying and Economic Growth," mimeo.

Hellman, Joel, Geraint Jones and Daniel Kaufmann, 2003. "Seize the State, Seize the Day: State Capture and Influence in Transition Economies," Journal of Comparative Economics, 31, 751-773.

Lambsdorff, Johann, 2002. “Corruption and Rent-seeking,” Public Choice, 113, 97-125.

Lehmbruch, Barbara, 1999. "Managing Uncertainty: Hierarchies, Markets and "Networks" in the Russian Timber Industry, 1991-1998,” BOFIT Discussion Papers, No. 4.

McFaul, Michael, 1993. "Russian Centrism and Revolutionary Transitions," Post-Soviet Affairs, 9, 196222.

Olson, Mancur, 1993. "Dictatorship, Democracy and Development," American Political Science Review, $87,567-576$.

Olson, Mancur, 1997. "The New Institutional Economics: The Collective Choice Approach to Economic Development," in ed. Christopher Clague, Institutions and Economic Development: Growth and Governance in Less-Developed and Post-Socialist Countries. Baltimore: Johns Hopkins University Press, 37-66.

Olson, Mancur, 2000. Power and Prosperity: Outgrowing Communist and Capitalist Dictatorships. New York: Basic Books.

Olson, Mancur, 1982. The Rise and Decline of Nations. New Haven: Yale University Press.

Przeworski, Adam, 1991. Democracy and the Market: Political and Economic Reforms in Eastern Europe and Latin America. Cambridge: Cambridge University Press.

Przeworski, Adam and Fernando Limongi, 1993. "Political Regimes and Economic Growth," Journal of Economic Perspectives, 7, 51-69.

Putnam, Robert, 1994. Making Democracy Work: Civic Traditions in Modern Italy, Princeton University Press.

Pyle, William, 2006a. "Collective Action and Post-Communist Enterprise: The Economic Logic of Russia’s Business Associations,” Europe-Asia Studies, 58, 491-521.

Pyle, William, 2005. "Contractual Disputes and the Channels for Inter-firm Communication," Journal of Law, Economics and Organization, 21, 547-575.

Pyle, William, 2006b. "Resolutions, Recoveries and Relationships: The Evolution of Payment Disputes in Central and Eastern Europe," Journal of Comparative Economics, 34, 317-337.

Rossiiskiie ob'edineniia predprinimatelei: spravochnik, 2001. Moscow: Institut predprinimatel'stva i investitsii.

Schneider, Ben Ross, 2004. Business Politics and the State in Twentieth-Century Latin America. Cambridge: Cambridge University Press.

Shleifer, Andrei and Robert Vishny, 1994. "Politicians and Firms," Quarterly Journal of Economics, 109, 995-1025. 
Solanko, Laura, 2003. "Why Favor Large Incumbents? A Note on Lobbying in Transition," BOFIT Online, No. 6.

Stoner-Weiss, Kathryn, 2006. Resisting the State: Reform and Retrenchment in Post-Soviet Russia. Cambridge: Cambridge University Press.

Sulakshin, S. and A. Romanikhin, 2003. "Ot 'profsoyuza oligarkhov' k profsoyuzu tovaroproizvoditelei," Voprosy ekonomiki, 1, 96-103.

Weingast, Barry, 1997. “The Political Foundations of the Rule of Law," American Political Science Review, 91, 245-264. 


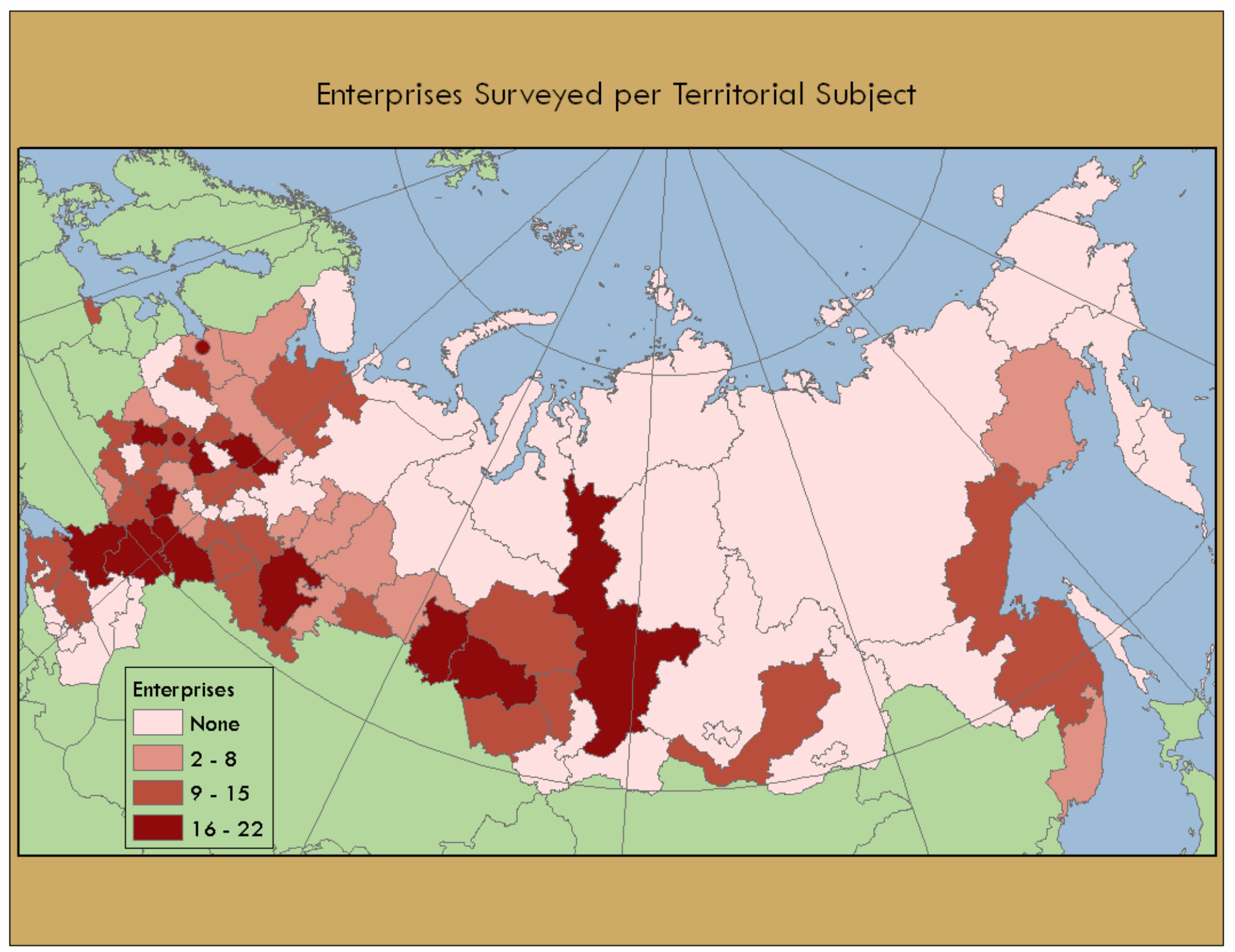


Table 1. Firms in survey sample belonging to a business association

$\begin{array}{lc} & \text { Percent of sample } \\ \text { Any type of association } & 46.2 \\ \text { Regional (any type) } & 39.4 \\ \quad \text { Regional, multi-sector } & 33.8 \\ \quad \text { Regional, sector-specific } & 7.9 \\ \text { Regional (any type), joined after } 1998 & 22.7 \\ \text { Regional (any type), joined in 1998 or before } & 18.8 \\ \text { Federal or multi-regional (any type) } & 9.6 \\ & \\ \text { Notes: Percentages based on questions which asked respondents about the two most im- } \\ \text { portant associations to which they belong; only 1.2\% of respondents to the screening sur- } \\ \text { vey reported being in more than two associations. }\end{array}$

Table 2. Basic statistics on firms in sample

\begin{tabular}{|c|c|c|}
\hline & $\begin{array}{l}\text { Not member of re- } \\
\text { gional association }\end{array}$ & $\begin{array}{l}\text { Member of regional } \\
\text { association }\end{array}$ \\
\hline Full-time employees in 2001 & 414.5 & 883.5 \\
\hline State-owned enterprise (\%) & 6.3 & 3.3 \\
\hline Member of commercial group (\%) & 20.2 & 24.3 \\
\hline Some foreign ownership (\%) & 9.0 & 12.2 \\
\hline Established after 1991 (\%) & 44.1 & 40.6 \\
\hline Located in a regional capital (\%) & 66.2 & 73.6 \\
\hline \multicolumn{3}{|l|}{ Sector $(\%)$} \\
\hline Metallurgy & 12.5 & 12.1 \\
\hline Chemicals & 14.7 & 22.2 \\
\hline Machine building \& metal working & 15.0 & 10.9 \\
\hline Construction materials & 14.7 & 10.5 \\
\hline Wood processing & 15.7 & 12.1 \\
\hline Light industry & 12.3 & 18.4 \\
\hline Food industry & 15.5 & 13.8 \\
\hline Observations & 367 & 239 \\
\hline
\end{tabular}

Notes: A "regional association" is taken to mean any association that draws its membership almost exclusively from a single region. A "commercial group" links together firms through ownership in a vertically or horizontally-integrated structures. 
Table 3. Years in which firms joined and associations founded

\begin{tabular}{|c|c|c|}
\hline & Regional association joined (\%) & Regional association formed (\%) \\
\hline Before 1990 & 2.3 & 4.9 \\
\hline 1990-1992 & 8.6 & 20.3 \\
\hline 1993-1995 & 12.5 & 23.1 \\
\hline 1996-1998 & 15.6 & 23.1 \\
\hline 1999-2001 & 39.5 & 16.8 \\
\hline 2002-2004 & 21.5 & 11.9 \\
\hline Observations & 256 & 143 \\
\hline
\end{tabular}

\section{Table 4. Services Provided by Regional Business Associations}

\begin{tabular}{|c|c|c|c|c|c|c|}
\hline & \multicolumn{4}{|c|}{$\begin{array}{l}\text { Percentage of members responding service } \\
\text { has noteworthy impact ( } 4 \text { or } 5 \text { on } 0-5 \text { scale) } \\
\text { on financial well-being }\end{array}$} & \multirow{2}{*}{\multicolumn{2}{|c|}{$\begin{array}{l}\text { Percentage of associations re- } \\
\text { sponding service important ( } 4 \text { or } 5 \\
\text { on } 0-5 \text { scale) feature of activities }\end{array}$}} \\
\hline & \multicolumn{2}{|c|}{ Full-time employees } & \multicolumn{2}{|c|}{ Joined association } & & \\
\hline & $<=100$ & $>100$ & $\begin{array}{l}1998 \text { or } \\
\text { before }\end{array}$ & $\begin{array}{l}\text { After } \\
1998\end{array}$ & At time of founding & Current \\
\hline $\begin{array}{l}\text { Lobbying govern- } \\
\text { ment officials }\end{array}$ & 19.4 & 23.2 & 21.6 & 24.0 & 71.5 & 84.7 \\
\hline $\begin{array}{l}\text { Participating in legis- } \\
\text { lative process }\end{array}$ & 18.1 & 19.7 & 14.9 & 21.4 & 54.9 & 83.4 \\
\hline $\begin{array}{l}\text { Protection from ille- } \\
\text { gitimate government } \\
\text { interference }\end{array}$ & 18.3 & 11.5 & 12.6 & 13.7 & 61.1 & 73.1 \\
\hline
\end{tabular}


Table 5. Regions in which firms surveyed

Pskovskaya oblast'

Smolenskaya oblast'

Arkhangel'skaya oblast'

Democracy index

Per capita income (2001)

Kaliningradskaya oblast'

Kaluzhskaya oblast'

Nizhegorodskaya oblast'

$\begin{array}{cc}5 & 26458 \\ 5 & 35447 \\ 4.5 & 50159 \\ 4.5 & 35551 \\ 4.5 & 32408 \\ 4.5 & 44957\end{array}$

Ryazanskaya oblast'

$\begin{array}{ll}4.5 & 35069 \\ 4.5 & 26235\end{array}$

Stavropolsky krai

Vladimirskaya oblast'

Kostromskaya oblast'

Krasnoyarsky krai

Kurganskaya oblast'

Leningradskaya oblast'

Tul'skaya oblast'

Volgogradskaya oblast'

Altaisky krai

Bryanskaya oblast'

Komi-Permyatskiy AO

Krasnodarsky krai

Lipetskaya oblast'

Moskovskaya oblast'

Novosibirskaya oblast'

$4.5 \quad 29004$

$4 \quad 31422$

$4 \quad 79657$

$4 \quad 25800$

$4 \quad 48372$

$4 \quad 32623$

$4 \quad 33173$

$3.5 \quad 27851$

$3.5 \quad 22938$

$3.5 \quad 82672$

$3.5 \quad 37010$

$3.5 \quad 42197$

$3.5 \quad 39642$

$3.5 \quad 39299$

$3.5 \quad 31723$

63825

Permskaya oblast'

34967

Primorsky krai

46572

Republic of Kareliya

Rostovskaya oblast'

Saint Petersburg

28470

58497

Tomskaya oblast'

59050

26611

Voronezhskaya oblast'

29246

Ulyanovskaya oblast'

Yaroslavskaya oblast'

Chelyabinskaya oblast'

51359

41974

56408

30813

Kurskaya oblast'

Magadanskaya oblast'

82625

Novgorodskaya oblast'

39990

Republic of Udmurtiya

Samarskaya oblast'

Sverdlovskaya oblast'

Tumenskaya oblast'

Orenburgskaya oblast'

43924

62106

46688

251982

Penzenskaya oblast'

Saratovskaya oblast'

Tambovskaya oblast'

Vologodskaya oblast'

Belgorodskaya oblast'

Moscow

Republic of Buratiya

Republic of Adygeya

Kemerovskaya oblast'

Republic of Bashkortostan

Republic of Tatarstan

Average

3.3

41874

23879

33602

27530

52655

35186

152196

30485

15596

39702

44994

57898

Notes: Incomes in 1000s of rubles. Sources: Democratic Audit of Russia; Yearbook Russia's Regions, Rosstat; 
Table 6. Membership in regional business associations

\begin{tabular}{|c|c|c|c|}
\hline & \multicolumn{3}{|c|}{ Became member of association } \\
\hline & Any time & 1998 or before & after 1998 \\
\hline Democracy (region) & $\begin{array}{c}0.086 \\
{[0.036]^{\star \star}}\end{array}$ & $\begin{array}{c}0.018 \\
{[0.020]}\end{array}$ & $\begin{array}{c}0.066 \\
{[0.028]^{\star \star}}\end{array}$ \\
\hline Log employees & $\begin{array}{c}0.120 \\
{[0.014]^{\star \star \star}}\end{array}$ & $\begin{array}{c}0.078 \\
{[0.012]^{\star \star \star}}\end{array}$ & $\begin{array}{c}0.037 \\
{[0.010]^{\star \star \star}}\end{array}$ \\
\hline Established post-1991 & $\begin{array}{c}0.109 \\
{[0.050]^{\star *}}\end{array}$ & $\begin{array}{c}0.046 \\
{[0.039]}\end{array}$ & $\begin{array}{c}0.079 \\
{[0.036]^{\star *}}\end{array}$ \\
\hline State-owned & $\begin{array}{l}-0.098 \\
{[0.096]}\end{array}$ & $\begin{array}{c}-0.157 \\
{[0.092]^{*}}\end{array}$ & $\begin{array}{c}0.000 \\
{[0.066]}\end{array}$ \\
\hline In regional capital & $\begin{array}{c}0.130 \\
{[0.040]^{\star \star \star}}\end{array}$ & $\begin{array}{c}0.120 \\
{[0.039]^{\star \star \star}}\end{array}$ & $\begin{array}{c}0.023 \\
{[0.036]}\end{array}$ \\
\hline Log income per capita (region) & $\begin{array}{l}-0.033 \\
{[0.048]}\end{array}$ & $\begin{array}{c}0.050 \\
{[0.026]^{*}}\end{array}$ & $\begin{array}{c}-0.113 \\
{[0.052]^{\star *}}\end{array}$ \\
\hline Sector controls & Yes & Yes & Yes \\
\hline Prob>chi2 & 0.0000 & 0.0000 & 0.0000 \\
\hline Pseudo R2 & 0.1127 & 0.1309 & 0.0527 \\
\hline Observations & 595 & 546 & 593 \\
\hline
\end{tabular}


Table 7. Does firm appeal and, if so, to whom in event of improper "unplanned inspection"?

\begin{tabular}{|c|c|c|c|c|c|c|}
\hline \multirow[b]{2}{*}{ Regional association member } & \multicolumn{2}{|c|}{ Does not appeal } & \multicolumn{2}{|c|}{ Local court } & \multicolumn{2}{|c|}{ Governmental bodies } \\
\hline & & $\begin{array}{c}-0.208 \\
{[0.054]^{\star \star \star}}\end{array}$ & & $\begin{array}{c}0.109 \\
{[0.040]^{\star \star \star}}\end{array}$ & & $\begin{array}{c}0.129 \\
{[0.033]^{\star \star \star}}\end{array}$ \\
\hline Democracy (region) & $\begin{array}{c}-0.066 \\
{[0.032]^{\star *}}\end{array}$ & $\begin{array}{l}-0.050 \\
{[0.033]}\end{array}$ & $\begin{array}{c}0.010 \\
{[0.031]}\end{array}$ & $\begin{array}{l}-0.000 \\
{[0.032]}\end{array}$ & $\begin{array}{c}0.048 \\
{[0.022]^{\star *}}\end{array}$ & $\begin{array}{c}0.036 \\
{[0.023]}\end{array}$ \\
\hline Log employees & $\begin{array}{c}-0.057 \\
{[0.024]^{\star \star}}\end{array}$ & $\begin{array}{c}-0.043 \\
{[0.025]^{\star}}\end{array}$ & $\begin{array}{c}0.063 \\
{[0.016]^{\star \star \star}}\end{array}$ & $\begin{array}{c}0.056 \\
{[0.017]^{\star \star \star}}\end{array}$ & $\begin{array}{c}0.042 \\
{[0.015]^{\star \star \star}}\end{array}$ & $\begin{array}{c}0.031 \\
{[0.015]^{\star *}}\end{array}$ \\
\hline Established post-1991 & $\begin{array}{c}-0.012 \\
{[0.059]}\end{array}$ & $\begin{array}{c}0.008 \\
{[0.056]}\end{array}$ & $\begin{array}{c}0.003 \\
{[0.047]}\end{array}$ & $\begin{array}{l}-0.007 \\
{[0.046]}\end{array}$ & $\begin{array}{c}0.050 \\
{[0.043]}\end{array}$ & $\begin{array}{c}0.035 \\
{[0.041]}\end{array}$ \\
\hline State enterprise & $\begin{array}{c}-0.039 \\
{[0.134]}\end{array}$ & $\begin{array}{l}-0.050 \\
{[0.137]}\end{array}$ & $\begin{array}{c}0.043 \\
{[0.108]}\end{array}$ & $\begin{array}{c}0.048 \\
{[0.107]}\end{array}$ & $\begin{array}{c}0.117 \\
{[0.104]}\end{array}$ & $\begin{array}{c}0.128 \\
{[0.100]}\end{array}$ \\
\hline Foreign owner influence & $\begin{array}{l}-0.055 \\
{[0.051]}\end{array}$ & $\begin{array}{l}-0.036 \\
{[0.053]}\end{array}$ & $\begin{array}{c}0.059 \\
{[0.030]^{\star \star}}\end{array}$ & $\begin{array}{c}0.049 \\
{[0.030]}\end{array}$ & $\begin{array}{c}0.022 \\
{[0.031]}\end{array}$ & $\begin{array}{c}0.008 \\
{[0.031]}\end{array}$ \\
\hline Commercial group & $\begin{array}{l}-0.059 \\
{[0.086]}\end{array}$ & $\begin{array}{l}-0.060 \\
{[0.082]}\end{array}$ & $\begin{array}{l}-0.014 \\
{[0.066]}\end{array}$ & $\begin{array}{l}-0.018 \\
{[0.064]}\end{array}$ & $\begin{array}{c}0.056 \\
{[0.054]}\end{array}$ & $\begin{array}{c}0.052 \\
{[0.050]}\end{array}$ \\
\hline Log income per cap. (region) & $\begin{array}{c}-0.126 \\
{[0.059]^{\star \star}}\end{array}$ & $\begin{array}{c}-0.124 \\
{[0.058]^{\star \star}}\end{array}$ & $\begin{array}{c}0.037 \\
{[0.081]}\end{array}$ & $\begin{array}{c}0.036 \\
{[0.081]}\end{array}$ & $\begin{array}{c}0.082 \\
{[0.038]^{\star \star}}\end{array}$ & $\begin{array}{c}0.080 \\
{[0.036]^{\star \star}}\end{array}$ \\
\hline Sector controls & Yes & Yes & Yes & Yes & Yes & Yes \\
\hline Observations & 334 & 334 & 334 & 334 & 334 & 334 \\
\hline Prob>chi2 & 0.0005 & 0.0000 & 0.0012 & 0.0000 & 0.0000 & 0.0000 \\
\hline Pseudo R2 & 0.0538 & 0.0807 & 0.0798 & 0.0949 & 0.1121 & 0.1382 \\
\hline
\end{tabular}

Notes: Marginal effects from probit model are reported; robust standard errors, adjusted for clustering at regional levels, in brackets; ${ }^{\star \star \star},{ }^{* \star},{ }^{*}$ significant at $1 \%, 5 \%$ and $10 \%$ levels, respectively. 
Table 8. Formalized participation in process of shaping new rules and regulations

\begin{tabular}{|c|c|c|c|}
\hline \multirow[b]{2}{*}{ Regional association } & $\begin{array}{l}\text { Past } 3 \text { years, invited } \\
\text { to participate in } \\
\text { working groups to }\end{array}$ & \multicolumn{2}{|c|}{$\begin{array}{c}\text { To what degree has been able to influence ac- } \\
\text { tual laws and regulations (1-4 scale) }\end{array}$} \\
\hline & $\begin{array}{c}0.135 \\
{[0.041]^{\star \star \star}}\end{array}$ & $\begin{array}{c}0.588 \\
{[0.196]^{\star \star \star}}\end{array}$ & $\begin{array}{c}2.538 \\
{[0.564]^{\star \star \star}}\end{array}$ \\
\hline Regional association $\mathrm{x}$ democracy (region) & & & $\begin{array}{c}-0.629 \\
{[0.169]^{\star \star \star}}\end{array}$ \\
\hline Democracy (region) & $\begin{array}{c}0.006 \\
{[0.036]}\end{array}$ & $\begin{array}{l}-0.049 \\
{[0.122]}\end{array}$ & $\begin{array}{c}0.345 \\
{[0.159]^{\star \star}}\end{array}$ \\
\hline Log employees & $\begin{array}{c}0.018 \\
{[0.014]}\end{array}$ & $\begin{array}{c}0.230 \\
{[0.079]^{\star \star \star}}\end{array}$ & $\begin{array}{c}0.229 \\
{[0.082]^{\star \star \star}}\end{array}$ \\
\hline Established post-1991 & $\begin{array}{c}-0.115 \\
{[0.050]^{\star \star}}\end{array}$ & $\begin{array}{c}0.083 \\
{[0.250]}\end{array}$ & $\begin{array}{c}0.123 \\
{[0.256]}\end{array}$ \\
\hline State enterprise & $\begin{array}{c}-0.232 \\
{[0.122]^{\star}}\end{array}$ & $\begin{array}{l}-0.255 \\
{[0.304]}\end{array}$ & $\begin{array}{l}-0.275 \\
{[0.316]}\end{array}$ \\
\hline Foreign owner influence & $\begin{array}{c}0.047 \\
{[0.030]}\end{array}$ & $\begin{array}{l}-0.012 \\
{[0.096]}\end{array}$ & $\begin{array}{c}-0.038 \\
{[0.097]}\end{array}$ \\
\hline Commercial group & $\begin{array}{c}0.016 \\
{[0.043]}\end{array}$ & $\begin{array}{l}-0.170 \\
{[0.244]}\end{array}$ & $\begin{array}{c}-0.281 \\
{[0.258]}\end{array}$ \\
\hline Log per capita income (region) & $\begin{array}{c}0.075 \\
{[0.057]}\end{array}$ & $\begin{array}{c}-0.457 \\
{[0.207]^{\star \star}}\end{array}$ & $\begin{array}{c}-0.357 \\
{[0.204]^{*}}\end{array}$ \\
\hline Sector controls & Yes & Yes & Yes \\
\hline Observations & 593 & 143 & 143 \\
\hline Prob>chi2 & 0.0000 & 0.0000 & 0.0000 \\
\hline Pseudo R2 & 0.0908 & .1358 & 0.1567 \\
\hline
\end{tabular}

Notes: Column 1, marginal effects from probit model are reported; columns 2 and 3, ordered probit model; obust standard errors, adjusted for clustering at regional levels, in brackets; ${ }^{\star \star \star},{ }^{* \star},{ }^{*}$ significant at $1 \%, 5 \%$ and $10 \%$ levels, respectively. 
Table 9. In previous three years, did firm invest in expanding or renovating capital stock?

$\begin{array}{lcc}\text { Regional association } & 0.061 & 0.489 \\ \text { Regional association x democracy (region) } & {[0.043]} & {[0.171]^{\star \star \star}} \\ & & -0.126 \\ \text { Democracy (region) } & & {[0.046]^{\star \star \star}} \\ & 0.073 & 0.115 \\ \text { Log employees } & {[0.027]^{\star \star}} & {[0.032]^{\star \star}} \\ & 0.083 & 0.084 \\ \text { Established post-1991 } & {[0.015]^{\star \star}} & {[0.015]^{\star \star}} \\ & 0.121 & 0.121 \\ \text { State enterprise } & {[0.051]^{\star}} & {[0.051]^{\star \star}} \\ & -0.117 & -0.092 \\ \text { Foreign owner influence } & {[0.114]} & {[0.124]} \\ & 0.016 & 0.011 \\ \text { Commercial group } & {[0.036]} & {[0.037]} \\ & 0.055 & 0.052 \\ \text { Log per capita income (region) } & {[0.042]} & {[0.042]} \\ & 0.098 & 0.097 \\ \text { Sector controls } & {[0.045]^{\star}} & {[0.047]^{\star \star}} \\ \text { Observations } & \text { Yes } & \text { Yes } \\ \text { Prob>chi2 } & 593 & 593 \\ \text { Pseudo R2 } & 0.0000 & 0.0000 \\ & 0.0907 & 0.0995\end{array}$

Notes: Marginal effects from probit model are reported; robust standard errors, adjusted for clustering at regional levels, in brackets; ${ }^{* * *},{ }^{* *},{ }^{*}$ significant at $1 \%, 5 \%$ and $10 \%$ levels, respectively. 